УДК $37.0(438)(092)$

DOI:

Олександра Янкович, доктор педагогічних наук, професор, завідувач кафедри педагогіки і методики початкової та дошкільної освіти Тернопільського національного педагогічного університету імені Володимира Гнатюка професор кафедри ранньої освіти, спеціальної педагогіки і ресоціалізаціі Куявсько-Поморської вищяої школи (м. Бидгощ, Польща)

\title{
ГРОМАДСЬКО-ОСВІТНЯ ДІЯЛЬНІСТЬ ТА ПЕДАГОГІЧНІ ПОГЛЯДИ МАРІЇ ЛОПАТКОВОЇ (1927-2016)
}

У статті здійснений усебічний аналіз життєвого шляху, творчої спадщини, громадської діяльності, спрямованої на відстоювання прав дітей, Марї Лопаткової, польської письменниці, освітньої діячки, засновниці напряму опікунсько-виховної діяльності - педагогіки серия. Відображено основні проблеми, які розв'язувала педагогиня. Виявлено ідеї, актуальні в українському освітньому просторі, вітчизняному шкільництві. Акцентовано увагуна обтрунтуванні М. Лопатковою дочільності поєднання педагогіки серия із сочіальною педагогікою.

Ключові слова: персонологія; М. Лопаткова; педагогіка серия; взаємодія “від серия до серия”; діти з обмеженими можливостями; опікунсько-виховна діяльність.

Jim. 15.

Oleksandra Yankovych, Doctor of Sciences (Pedagogy), Professor, Head of the Pedagogy and Methods of Primary and Preschool Education Department Ternopil Volodymyr Hnatyuk National Pedagogical University Professor of Early Education, Spesial Pedagogy and Resocialization Department, Kujawy and Pomorze University in Bydgoshch

\section{PUBLIC-EDUCATIONALACTIVITIES AND PEDAGOGICALVIEWS OF MARIYA LOPATKOVA (1927-2016)}

The article provides a comprehensive analysis of life, creative heritage, public activities aimed at defending the rights of children, of Mariya Lopatkova, Polish writer, influential figure in education, founder of the direction of guardianship and educational activities - pedagogy of heart.

The main problems solved by the M. Lopatkova have been reflected: democratization of the school life, increasing the attention to children with disabilities, building a happy society. The necessity of restoring the priority of love over material values; the need to eliminate competition in primary schools have been shown. M. Lopatkova emphasized the need for love, mutual understanding and friendship as the leading values of pedagogy of heart, without which spiritual injury occurred.

The ideas relevant in the Ukrainian educational space and the school system have been revealed. They are the following: realization of the program "To kindergarten without crying"; communication in schools on the basis of pedagogy of heart; development of the pupils' intelligence simultaneously with their emotional and social development; care for a child with disabilities from the society, the school, educational institutions; creating opportunities for his/her comprehensive development; combination of pedagogy of heart with social pedagogy; training a prospective teacher who is an example to follow, loves children and defends their rights; forming an educational ideal - a perfect person, who combines significant achievements with modesty, the desire to provide help and support to those who need it; building a happy society on the bases of rapprochement with nature, spirituality restoration, overcoming social injustice in politics and economics, elimination of bureaucracy from public life, counteraction to selfishness, aggression, greed.

Keywords: personology; M. Lopatkova; pedagogy of hear; interaction "from heart to heart"; children with disabilities; guardianship and educational activities.

П остановка проблеми. Одним 3 орієнтирів для розвитку Нової української школи є погляди класиків педагогіки щодо реалізації форм, методів, засобів освітнього процесу. Свроінтеграційні прагнення спонукають до виявлення актуальних ідей у працях відомих зарубіжних діячів. Близькою для українських освітян $є$ педагогіка серця, яку розвивали Ш. Амонашвілі, Я. Корчак, Г. Сковорода, В. Сухомлинський. Проте маловідомою або й невідомою є спадщина польської письменниці, громадської діячки, активної захисниці прав дітей, учительки початкової школи Марії Лопаткової (Maria Jopatkowa). Вона авторка численних праць iз педагогіки, найвідомішою з яких є видана в 1992 p. “Педагогіка серця". 
Аналіз останніх досліджень і публікацій. Проблеми розвитку шкільної освіти в Польщі $\epsilon$ предметом досліджень українських учених (К. Біницької, А. Василюк, Т. Кристопчук, I. Кузьми, С. Сисоєвої, В. Шахова та ін.), польських науковців (Ч. Купісевича (Cz. Kupisiewicz), А. Пашкевич (А. Paszkiewicz), Б. Суходольського (B. Suchodolski), Й. Шиманської (J. Szymańską) та ін.). У працях цих дослідників розглядаються тенденції реформ та інновації в освітній галузі Польщі. Низка наукових робіт (Д. Клюс-Станська (D. Klus-Stańska), Б. Муравська (B. Murawska), М. Щепська-Пустовська (M. Szczepska-Pustkowska) тощо) присвячена розвитку початкової освіти. Серед освітніх проблем на особливу увагу заслуговує реалізація педагогіки серця, оскільки в сучасному світі відчувається нестача любові, щирого ставлення до ближнього, а особливо до дитини.

Окремі аспекти взаємодії “від серця до серця” відображені у працях А. Крати, І. Кузьми, О. Янкович [3], [6]. Ідеї педагогіки серця, які розвивала М. Лопаткова, висвітлені в працях польських учених, а саме: Й. Глієра (J. Glier), Б. Серадзької-Базюр (В. Sieradzka-Baziur), I. Вагнер (I. Wagner) тощо. Попри визнання заслуг М. Лопаткової, є дослідження, у яких ідеї польської діячки розглядають як утопічні. Зокрема, на це вказує Е. Пецух (E. Piecuch). Вона зауважила суперечність у поглядах авторки "Педагогіки серця": з одного боку, М. Лопаткова вважає, що дитина може подати позов на батьків у суд, якщо вони погано виконують свої обов'язки, а 3 іншого - переконана, що навіть наймудріша дитина не має права керувати домом $[12,195]$. Проте критики педагогіки М. Лопаткової одностайні в тому, що домінувальною ідеєю всетаки є ставлення до дитини з любов'ю; на основі любові необхідно створювати умови для розвитку дитини $[12,195]$. Гуманістичні засади педагогіки серця зумовлюють iï актуальність у сучасному світі.

Отже, постать М. Лопаткової як письменниці, учительки, захисниці прав дітей заслуговує на увагу українських освітян із позицій, що їх накреслила I. Розман. Науковець зауважила: "Розроблена в персонології методологія структурно-особистісного аналізу орієнтує вчених на комплексний інтегративний підхід до вивчення педагогічної персоналії, який передбачає врахування як загальної, властивої всім людям, так і її власної унікальної “конструкції” $[1,89]$.

У працях українських науковців знаходимо лише поодинокі спогади про М. Лопаткову (І. Кузьма, Г. Терещук, Г. Фальфушинська, О. Янкович) [2],
[14]. Отже, актуальною є мета статті: усебічний аналіз життєвого шляху, творчої спадщини, громадської діяльності, спрямованої на відстоювання прав дітей, Марії Лопаткової та використання iї ідей в українському освітньому просторі.

Для досягнення цілей статті використано низку методів досліджень, що реалізуються при вивченні персоналії: пошуково-бібліографічний, генетичний, проблемно-хронологічний, а також зіставно-порівняльний аналіз літературних джерел та інтерпретаційно-аналітичний, що передбачали інтерпретацію, порівняння, систематизацію фактів наукової літератури та їхнє узагальнення.

Виклад основного матеріалу. М. Лопаткова народилася 28 січня 1927 р. у Мадзійовіцах (Мазовецьке воєводство). У 1948-1952 рр. вона навчалася в Лодзькому університеті на факультеті польської філології. У 1968 р. стала доктором педагогіки у Варшавському університеті. 3 1947 р. до 1969 р. працювала вчителем початкової школи в Лодзі, у сільській школі в Модліці (у цій школі також виконувала функції директора), в Олтажеві. Керувала аматорським театральним колективом [8].

У 1969-1971 рр. була головним редактором видання “Приятель дитини". У 1972-1980 рр. М. Лопаткову обрали депутатом Сейму ПНР (Польської Народної Республіки). Датою, важливою з погляду польських активістів у сфері захисту прав дитини, було 21 листопада 1981 р. заснування Комітету захисту прав дитини. Саме М. Лопаткова була ініціаторкою створення цієї першої у Східній Європі неурядової організації, що зосереджує свої зусилля на реалізації основних прав дитини (людини). Працюючи в Комітеті захисту прав дитини, М. Лопаткова сприяла впровадженню за участі владних освітніх структур програми “До дитячого садка, не плачучи” [10, 154]. Ця програма передбачала ранній запис до дитячого садка; взаєморозуміння між батьками, дітьми й вихователями; інформування батьків про діяльність закладу дошкільної освіти. Управлінські освітні органи, переконані в ефективності опікунсько-виховної системи, не чули плачу дитини, що приходила до дитсадка, але його чула М. Лопаткова. Вона вирішила не зволікати [5, 48].

Комітет, прагнучи реалізації головної мети допомогти скривдженій дитині та їі сім'ї, діяв через свої регіональні відділення у всій Польщі.

У 1988 р. М. Лопаткова створила Товариство допомоги молоді. Усвідомлюючи, що може допомогти дітям як політик, у 1993 р. ініціювала створення Партії дитини, яка згодом 
реорганізована в Партію дітей та молоді. Була сенатором, а згодом керівником сенатської комісії науки і народної освіти в Сеймі у 1993-1997 pp.

Доктор М. Лопаткова співпрацювала 3 багатьма вищими школами, у яких здійснювалася підготовка педагогів. В останні роки життя викладала в Академії спеціальної педагогіки імені Марії Гжегожевської [8].

М. Лопаткова є засновником педагогічного напряму й опікунсько-виховної діяльності, що у світовій педагогіці отримали назву “педагогіка серця" $[12,185]$. Цей напрям є глибоко гуманістичним. Він викристалізувався на основі наукових праць, багаторічної педагогічної практики, інших джерел. Предметом педагогіки серця є способи, умови співпраці, спілкування на засадах “від серця до серця”, що передбачає порозуміння без насильства $[6,73]$.

Ідеї виховання з любов'ю до дитини, що зараз ми називаємо педагогікою серця, у свій час розвивали італійський священник (нині святий), покровитель молоді Ян Боско, польський лікар, педагог, письменник, публіцист і суспільний діяч Януш Корчак, український філософ, мислитель Григорій Сковорода, український педагог Василь Сухомлинський, грузинський педагог і психолог Шалва Амонашвілі [3, 58]. На початку 90-х pp. XX ст. настав новий етап зацікавлення педагогікою серця.

У 1992 р. М. Лопаткова написала книжку “Педагогіка серця", постулати якої актуальні й зараз. Авторка звернула особливу увагу на любов у житті людини, зокрема в процесі виховання. Вона писала: “Любов $є$ прекрасне і величне почуття, навіть тоді, коли проявляється в елементарній формі без великих емоцій. Її найвищим виміром $\epsilon$ готовність віддати життя за того, кого любиш" $[10,33]$. Отже, любов - це загальнолюдська і позачасова цінність. Вона об'єднує людей, незважаючи на різноманітні поділи: політичні, культурні, расові... [10, 28]. “Якщо з'являється любов, іiі треба плекати так, як дитину, рідну мову, троянди в саду... Це означає, що треба турбуватися про іï розвиток і не допускати кривди" [10, 49], [4, 50].

Педагог, учитель, просвітницький діяч, речник і захисник прав дітей у Польщі, автор книг - це лише частина $з$ того, що робила М. Лопаткова. Вона повністю віддавалася допомозі наймолодшим - була голосом дітей. Постійно підкреслювала, що необхідно турбуватися про дитину, оскільки це найнезахищеніша, найслабша істота на землі. Головний здобуток боротьби за права дитини - це їі добро.

Любов, взаєморозуміння та дружба відіграють провідну роль у педагогіці серця, адже ці цінності $\epsilon$ найважливішими в житті.

У повсякчас зайнятому суспільстві, що набирає чимраз більших темпів розвитку, ми живемо в дедалі більшому стресі; у дивному божевільному світі, у якому вже ніхто нікому не вірить. Ми часто гонимося за матеріальними благами, такими як нова машина чи гроші на екзотичний відпочинок, забуваючи про найважливіші цінності, а саме про любов. Речі можна втратити, а справжня любов залишається на все життя, бо “чого варте життя, якщо в ньому немає любові?” [10, 27].

Для дитини найважливішими $є$ перші п'ять років їі життя. Діти, яких обіймають і пестять, розвиваються краще, ніж ті, які виховуються у сім'ях без ніжності або в закладах опіки.

Прагнення любові, у чому I. Вагнер (I. Wagner) погоджується з М. Лопатковою, яке незадовольняється в дитинстві, дається взнаки в майбутньому. Зовні може бути непомітно, однак люди відрізняються залежно від того, чи відчували любов у дитячі роки. Найгірше, що ліків від цього немає $[15,271]$.

Нестача почуття захищеності в ранньому дитинстві проявляється смоктанням пальців, розгойдуванням, похитуванням голови, що часто притаманно дітям-сиротам. Смоктання пальців спостерігається також у дітей із люблячих сімей, але якщо це повторюється систематично, то повинно стати сигналом для батьків, що дитина відчуває емоційну недостатність.

М. Лопаткова стверджувала, що любов - це велика емоційна сила, яка може змінити на краще навіть найбільших грішників $[4,51]$. Найчисленнішою групою неслухняних та тих, які не хочуть навчатися, $\epsilon$ діти із сімей, де не проявлялися любов і турбота. Діти, про яких піклуються 3 любов'ю та сердечністю, з часом стають ніжнішими до свого оточення. Ось чому авторка "Педагогіки серця" зауважує, що необхідно використовувати всі можливості для взаємного збагачення розуму і почуття.

Наступною важливою проблемою, що турбувала Марію Лопаткову, є ставлення учня до школи. Чи дитина полюбить школу, чи ні, залежить найбільше від перших років навчання. Що менша дитина, то більше вона переймається успіхами в школі. Часто, однак, так трапляється, що учень не може відповідати визначеним вимогам. Це одна $з$ причин шкільних невдач як у молодших, так і в старших класах, що призводить до страху перед закладом освіти і до сильних негативних переживань, а в старших класах навіть до самогубств [5, 50-51]. М. Лопаткова домагалася, щоб школа стала такою, яку учні приймають, 
тобто щоб не викликала страху і була привабливою, а також розвивала дітей духовно $[5,51]$.

Авторка "Педагогіки серця" не підтримувала створення конкурентного середовища в школах, оскільки, на ㄲï думку, при цьому втрачається головне - гуманізм людських стосунків, який має існувати не лише в закладах освіти, але й у суспільстві: “Культи красивої зовнішності, здоров'я, освіти, заможності, підприємливості, конкуренції, успіху спричиняють почуття неповноцінності у щораз більшої кількості людей, які не вирізняються такими якостями. Усвідомлення, що ти не $є$ привабливим, заповзятим, породжує неспокій, страх самотності тощо" [10, 27], [2, 35], [4, 40]. Перед М. Лопатковою постало складне питання: як спрямувати людство до щастя? Вона дійшла висновку: хоча це й складно зробити, але реально $[10,26],[4,40]$. Розв'язанню проблеми, як врятувати світ, допомогти людям бути щасливими, присвячені їі життя й творчість. Концепція порятунку людства М. Лопаткової заснована на таких принципах: зближення 3 природою, відновлення духовності, подолання соціальної несправедливості в політиці й економіці, усунення бюрократії з публічного життя, протидія егоїзму, агресії, жадібності $[4,40]$.

3 позицій педагогіки серця М. Лопаткова турбувалася про виховання дітей з обмеженими можливостями.

Польська письменниця вважала, що діти в лікарнях, особливо ті, які страждають від невиліковних хвороб, повинні грати і бігати скільки завгодно і скільки мають сили. "Нехай вони бігають, - стверджувала педагог, - поки можуть, і не лише в лікарняних коридорах та кімнатах, а й у саду з різними ігровими пристроями" $[5,54]$. М. Лопаткова не розуміла, чому в дитячих лікарнях немає дитячих майданчиків? Чому дитячі майданчики лише є для здорових? [5, 54].

Авторка "Педагогіки серця” була переконана, що хворі діти з різними фізичними чи психічними вадами, поки не потрапляють до лікарні, повинні ходити до школи, якщо можуть вчитися разом 3 однолітками. Потрібно зробити все, щоб дати їм змогу здобувати освіту таким чином. 3 іншого боку, якщо хвороба унеможливлює перебування в школі, а навчати можна лише індивідуально, це навчання має поєднуватися 3 привабливими видами діяльності, які могли б відвідувати і друзі пацієнта [5, 54].

Здорові дорослі часто вважають, що не варто інтегрувати хворих дітей 3 обмеженими можливостями в суспільство, тобто, щоб ніхто їх не бачив. У такий спосіб намагаються захистити таких дітей від жалю та співчуття оточення, якого, однак, не хоче зазнати жодна особа. Це немислимо неправильно, уважає М. Лопаткова, тому що людина, котра і так сумує через своє нездужання, почуватиметься ще гірше, коли ми замкнемо іiі у чотирьох стінах та ізолюємо від навколишнього середовища. Така дитина втратить наявні і не встановить потенційні зв'язки 3 однолітками та суспільством, вона від них відчужиться. Ми не можемо захистити їі від нетактовних коментарів і дивних поглядів, але не треба ще більше руйнувати психічний стан дитини, яку вже і так турбує інвалідність.

Розучування нових ігор та участь у забавах, читання цікавих книг, перегляд фільмів, знайомство з технічними іграшками та приладами сприяли б тому, щоб друзі охоче відвідували хвору дитину, і кожен би чудово проводив час.

Авторка "Педагогіки серця" наголошувала на тому, що маленькі мученики, відокремлені від світу хронічними хворобами чи інвалідністю, дуже потребують контакту зі своїми однолітками. “Сумно, - $з$ болем писала М. Лопаткова, - що хворих дітей, які роками прикуті до ліжка, мають фізичні вади, аутисти, шизофреніки, мають церебральний параліч, погіршення зору, втрату слуху та багато інших вад здоров'я, немає в дитячих садках, школах чи на дитячих майданчиках" [у сучасній науковій літературі вважаємо за необхідне використовувати поняття “дитина 3 аутизмом”, “дитина 3 шизофренією” тощо - прим. автора] [4, 54]. Проте суспільство часто не хоче розділяти такі погляди.

М. Лопаткова досліджувала ставлення до невиліковно хворих дітей у багатьох країнах. Вона зробила короткий висновок - погано. Лише в окремих країнах створені засади й механізми, що сприяють підтримці таких дітей [5, 54-55].

Авторка "Педагогіки серця" стверджувала, що в Польщі, як і в багатьох інших країнах, турбота про хворих дітей перекладена на плечі батьків. Це передусім результат розповсюджених стереотипів, що батьки, благодійні й релігійні організації мають обов'язок опікуватися такими дітьми. Так це розуміє центральна і місцева влада. Світ лише словесно дотримується елементарного принципу справедливості. Водночас що більше обділена дитина, то більше про неї мають турбуватися батьки, суспільство та держава $[5,55]$.

Такий ганебний стан справ вимагає негайних i широкомасштабних дій, зокрема поєднання педагогіки серия із соиіальною педагогікою, уважала М. Лопаткова [5, 55]; [10, 205].

Необхідно зруйнувати стереотипи мислення та 
дії, які виштовхують дітей із відхиленнями в розвитку за межі соціального життя. Потрібно звертатися до фахівців, які можуть допомогти розв’язати наявні проблеми. Люди повинні знати, що дитина, засуджена на смерть невиліковною хворобою, має право відчувати радість так само, як здорові діти; що дитину з розумовою відсталістю треба поважати, як і будь-кого іншого; що дитина 3 інвалідністю може компенсувати свою рухову втрату досягненнями в інших галузях. Зрештою, саме від нас, дорослих, залежить, скільки радості відчують діти 3 обмеженими можливостями.

Відповідно до гуманістичних принципів М. Лопаткова визначила вимоги до вчителя. Він не тільки повинен навчати учнів, але й формувати їхні альтруїстичні переконання. Навчити любові неможливо за допомогою диктатури, владних наказів. Іноді потрібно так мало, щоб зрозуміти проблеми дітей і поглянути ласкавішим оком.

У сучасній школі на початку XXI ст. важливо приділяти увагу не тільки навчанню, але передусім емоційному і соціальному розвитку учнів. А зробити це може лише вчитель, який сам здатний на прояви гуманістичної поведінки, має силу плекати людяність. Такими $є$ педагоги, які люблять дітей (тоді діти відповідатимуть взаємністю), які є прикладом для наслідування й захоплення. Саме такі вчителі нового покоління потрібні школі.

М. Лопаткова висловила цікаві думки щодо успішних людей. На ¥ї думку, люди, які $€$ досконалими, але скромними, відданими своїй справі, підтримують інших, викликають повагу, любов і захоплення. Тоді як люди досконалі, але які вивищуються над іншими, досягають висот лише заради власної слави, гордості та підтвердження своєї важливості, можуть викликати захоплення, але ніколи не заслуговують любові та поваги $[15,271]$. Отже, людина, яка вважає себе вищою від інших, приречена на відчуження й самотність [4, 39].

Висновки. У період реформування школи на засадах гуманізму виникає інтерес до творчості педагогів, що розвивали ідеї педагогіки серця. Маловідомою або й невідомою для українських освітян є постать Марії Лопаткової - польської письменниці, освітньої та громадської діячки.

Низка iї ідей зберігає актуальність в умовах побудови Нової української школи:

- реалізація програми “До дитячого садка, не плачучи";

- спілкування в школах на засадах педагогіки серця;

- розвиток інтелекту учнів водночас із їхнім емоційним та соціальним розвитком;
- турбота про дитинуз обмеженими можливостями зі сторони суспільства, школи, виховних інституцій; створення можливостей для її всебічного розвитку; поєднання педагогіки серця 3 соціальною педагогікою;

- підготовка у ЗВО вчителя, який є прикладом для наслідування, любить дітей і відстоює їх права;

- формування виховного ідеалу - досконалої людини, у якій вагомі здобутки поєднані зі скромністю, прагненням надавати допомогу й підтримку тим, хто їі потребує;

- побудова щасливого суспільства на принципах зближення з природою, відновлення духовності, подолання соціальної несправедливості в політиці й економіці, усунення бюрократії 3 публічного життя, протидія егоїзму, агресії, жадібності.

Перспективним напрямом подальших наукових студій $\epsilon$ всебічне вивчення проблеми самотності дитини на основі творчості М. Лопаткової.

\section{ЛІТЕРАТУРА}

1. Розман I. Структурно-особистісні аспекти вивчення педагогічної персоналії. Молодь $і$ ринок: науково-педагогічний журнал. Дрогобич, 2020. № 1 (180). С. 89-93.

2. Янкович О. І. Шкільництво Сінгапуру крізь призму реформування освітньої галузі України. Наукові записки ТНПУ ім. В. Гнатюка. Серія Педагогіка. 2019. № 1. C. 29-36.

3. Янкович О. І., Янкович I. І. Метод взаємодії “від серця до серця" в українській та зарубіжній педагогіці. Таврійський вісник освіти. 2016. № 1 (53). C. 56-59.

4. Glier J. Podstawy filozoficzne pedagogiki serca oraz psychologiczna koncepcja człowieka Marii Łopatkowej. Przegląd Pedagogiczny. 2015. No. 2. S. 38-57. URL: file:/ // C:/ Users / admin/Downloads/Joachim\%2 0Pawe\%20\%20Gli er\%20Podstaw y\%20filozoficzn e\%20pedagogiki\% 20serca\%20oraz\% 20psycholog iczna\%20koncepc ja\%20 czlowieka \%20Mari i\%20Lopatkowej\%20(6).pdf

5. Glier J. Postulaty Marii Łopatkowej w zakresie zmian w oświacie... oraz prawie rodzinnym i opeikuńczym. Studia z Teorii Wychowania: półrocznik Zespołu Teorii Wychowania Komitetu Nauk Pedagogicznych PAN. 2013. 4/2 (7), S. 47-69.

6. Krata A. Porozumienie bez przemocy w szkole. W: Profilaktyka w szkole: Poradnik dla nauczycieli. Warszawa: Centrum Metodyczne Pomocy PsychologicznoPedagogicznej, 2005. S. 65-83.

7. Luber D. Ideał wychowawcy małego dziecka w kontekście aksjologicznych dociekań. Nauczyciel i Szkoła. 2012. No 2 (52). S. 53-65.

8. Łopatkowa Maria. URL: http://encyklopedia dziecinstwa.pl/index.php/\%C5\%81opatkowa_Maria

9. Łopatkowa M. O prawną ochronę więzi uczuciowej 
dziecka. Biuro Studiów i Analiz Kancelarii Senatu. Seria: Materialy. Warszawa, 1996. $4 \mathrm{~s}$.

10. Łopatkowa M. Pedagogika serca. Warszawa: Wydawnictwo Szkolne i Pedagogiczne (WsiP), 1992. $225 \mathrm{~s}$.

11. Łopatkowa M. Samotność dziecka. Warszawa: WSiP, $1989.260 \mathrm{~s}$.

12. Piecuch E. Utopijna wizja wychowania pedagogiki serca Marii Łopatkowej w kontekście wartości czasów współczesnych. Utopia a edukacja. Wrocław: Instytut Pedagogiki Uniwersytetu Wrocławskiego, 2016. T. 1. S. 186198. URL: https://repozytorium.uni.wroc.pl/dlibra/ publication/81204/edition/78790/utopijna-wizja-wychowaniapedagogiki-serca-marii-lopatkowej-w-kontekscie-wartosciczasow-wspolczesnych-piecuch-ewelina?language=pl

13. Sieradzka-Baziur B. Wychowanie emocjonalne w XXI wieku według pedagogiki serca Marii Łopatkowej. Studia Paedagogica Ignatiana. Rocznik Wydziatu Pedagogicznego Akademii "Ignatianum" w Krakowie. 2017. No 20/2. S. 255-258

14. Tereshchuk H. V., Kuzma I. I., Yankovych O. I., Falfushynska H. I. The formation of a successful personality of a pupil in Ukrainian primary school during media education implementation. Cloud Technologies in Education. Proceedings of the 6th Workshop CTE 2018 (Kryvyi Rih, Ukraine, December 21, 2018) / Eds. Kiv, A. E., Soloviev, V. N. CEUR-WS.org, online. P. 145-158. URL: http://ceur-ws.org/Vol-2433/paper08.pdf

15. Wagner I. Miłość do najbliższych jako czynnik stymulujący transgresję. Studia Dydaktyczne. 2012. No 24. S. 265-272. URL: http://dydaktyka.uni.lodz.pl/wpcontent/uploads/2015/07/016_Wagner_Iwona_pop.pdf

\section{REFERENCES}

1. Rozman, I. (2020). Strukturno-osobystisni aspekty vyvchennia pedahohichnoi personalii [Structural and personal aspects of the study of pedagogical personality]. Youth \& the Market: scientific and pedagogical journal. Drohobych. No. 1 (180). pp. 89-93. [in Ukrainian].

2. Yankovych, O. I. (2019). Shkilnytstvo Sinhapuru kriz pryzmu reformuvannia osvitnoi haluzi Ukrainy [The school system of Singapore through the prism of reforming the education sphere of Ukraine]. Scientific notes of V. Hnatiuk TNPU. Series Pedagogy. No. 1. pp. 29-36. [in Ukrainian].

3. Yankovych, O. I. \& Yankovych, I. I. (2016). Metod vzaiemodii "vid sertsia do sertsia" v ukrainskii ta zarubizhnii pedahohitsi [The method of interaction "from heart to heart" in Ukrainian and foreign pedagogy]. Taurian Bulletin of Education. No. 1 (53). pp. 56-59. [in Ukrainian].

4. Glier, J. (2015). Podstawy filozoficzne pedagogiki serca oraz psychologiczna koncepcja człowieka Marii Łopatkowej [Philosophical foundations of pedagogy of heart and the psychological concept of a person by Maria Lopatkowa]. Pedagogical Review. No. 2. pp. 38-57. Available at: file://C:/Users/admin/Downloads/ Joachim $\% 20$ Pawe $\% 20 \% 20$ Glier $\% 20$ Podstawy $\% 20$ filozof iczne $\% 20$ pedagogi ki\%20serca\%2 0oraz\%20psychol ogiczna\% 20koncepc ja\%20czlowieka\% 20Marii\%20 Lopatkowej\%20(6).pdf [in Polish].

5. Glier, J. (2013). Postulaty Marii Łopatkowej w zakresie zmian w oświacie... oraz prawie rodzinnym i opeikuńczym
[Maria Lopatkowa's postulates regarding changes in education ... as well as family and guardianship law]. Studies in the Theory of Education. 4/2 (7). pp. 47-69. [in Polish].

6. Krata, A. (2005). Porozumienie bez przemocy w szkole [Agreement without violence at school]. In: Prevention at school: A guide for teachers. Warsaw: Methodological Center for Psychological and Pedagogical Assistance, pp. 65-83. [in Polish].

7. Luber, D. (2012). Ideał wychowawcy małego dziecka w kontekście aksjologicznych dociekań [The ideal of a small child's educator in the context of axiological investigations]. A Teacher and a School. No.2 (52). pp. 53-65. [in Polish].

8. Łopatkowa Maria. Available at: http://encyklopedia dziecinstwa.pl/index.php/\%C5\%81opatkowa_Maria [in Polish]

9. Łopatkowa, M. (1996). O prawną ochronę więzi uczuciowej dziecka [For the legal protection of a child's emotional connection]. Office of Studies and Analysis of the Senate Chancellery. Series: Materials. Warsaw, 4 p. [in Polish].

10. Łopatkowa, M. (1992). Pedagogika serca [Pedagogy of heart]. Warsaw: School and Pedagogical Publishing House, 225 p. [in Polish].

11. Łopatkowa, M. (1989). Samotność dziecka [The loneliness of a child]. Warsaw: School and Pedagogical Publishing House, 260 p. [in Polish].

12. Piecuch, E. (2016). Utopijna wizja wychowania pedagogiki serca Marii Łopatkowej w kontekście wartości czasów współczesnych [Utopian vision of educating the pedagogy of heart by Maria Łopatkowa in the context of the values of modernity]. Utopia and education. Wrocław: Institute of Pedagogy of the University of Wrocław. Vol. 1.pp. 186-198. Available at: https://repozytorium.uni.wroc.pl/ dlibra/publication/81204/edition/78790/utopijna-wizjawychowania-pedagogiki-serca-marii-lopatkowej-wkontekscie-wartosci-czasow-wspolczesnych-piecuchewelina? language $=$ pl_[in Polish].

13. Sieradzka-Baziur, B. (2017).Wychowanie emocjonalne w XXI wieku według pedagogiki serca Marii Łopatkowej [Emotional education in the 21 st century according to the pedagogy of heart by Maria Łopatkowa]. Paedagogica Ignatiana studies. Yearbook of the Pedagogical Faculty of the "Ignatianum" Academy in Kraków. No 20/2.pp. 255258. [in Polish].

14. Tereshchuk, H. V., Kuzma, I. I., Yankovych, O. I. \& Falfushynska, H. I. (2018). The formation of a successful personality of a pupil in Ukrainian primary school during media education implementation. Cloud Technologies in Education. Proceedings of the 6th Workshop CTE 2018 (Kryvyi Rih, Ukraine, December 21, 2018) / Eds. Kiv, A. E., Soloviev, V. N. CEUR-WS.org, online. pp. 145158. Available at: http://ceur-ws.org/Vol-2433/paper08.pdf [in English].

15. Wagner, I. (2012). Miłość do najbliższych jako czynnik stymulujący transgresję [Love for our closest relatives as a factor stimulating transgression]. Didactic Studies. No. 24. pp. 265-272. Available at: http:// dydaktyka.uni.lodz.pl/wp-content/uploads/2015/07/ 016_Wagner_Iwona_pop.pdf_[in Polish].

Стаття надійшла до редакції 06.10.2020 